\title{
PKCepsilon and an increase in intracellular calcium concentration are necessary for PGF2alpha to inhibit LH-stimulated progesterone secretion in cultured bovine steroidogenic luteal cells
}

\author{
Madhusudan P Goravanahally ${ }^{1}$, Aritro Sen ${ }^{1,2}$, Emmet K Inskeep ${ }^{3}$ and \\ Jorge A Flores*1
}

Address: ${ }^{1}$ Department of Biology, West Virginia University, Morgantown, West Virginia, USA, ${ }^{2}$ Department of Animal Sciences, Michigan State University, East Lansing, Michigan, USA and ${ }^{3}$ Animal and Veterinary Sciences, West Virginia University, Morgantown, West Virginia, USA

Email: Madhusudan P Goravanahally - mgoravan@mix.wvu.edu; Aritro Sen - aritros@msu.edu; Emmet K Inskeep - einskeep@wvu.edu; Jorge A Flores* - jflores@wvu.edu

* Corresponding author

Published: 30 August 2007

Reproductive Biology and Endocrinology 2007, 5:37 doi:10.1186/1477-7827-5-37

This article is available from: http://www.rbej.com/content/5/1/37

(c) 2007 Goravanahally et al; licensee BioMed Central Ltd.

This is an Open Access article distributed under the terms of the Creative Commons Attribution License (http://creativecommons.org/licenses/by/2.0), which permits unrestricted use, distribution, and reproduction in any medium, provided the original work is properly cited.

\begin{abstract}
The hypotheses that PKCepsilon is necessary for: I) PGF2alpha to inhibit LH-stimulated progesterone (P4) secretion, and 2) for the expression of key prostaglandin synthesizing/metabolizing enzymes were tested in bovine luteal cells in which PKCepsilon expression had been ablated using a validated siRNA protocol. Steroidogenic cells from Day -6 bovine corpus luteum $(\mathrm{CL})$ were isolated and transfected to reduce PKCepsilon expression after 48, 72 and $96 \mathrm{~h}$. A third tested hypothesis was that an increase in intracellular calcium concentration $([\mathrm{Ca}(2+)] \mathrm{i})$ is the cellular mechanism through which PGF2alpha inhibits luteal progesterone. The hypothesis was tested with two pharmacological agents. In the first test, the dosedependent effects on raising the $[\mathrm{Ca}(2+)]$ i with the ionophore, A23।87, on basal and $\mathrm{LH}$-stimulated $\mathrm{P} 4$ secretion in cells collected from early (Day -4) and mid-cycle (Day -10) bovine CL was examined. In the second test, the ability of PGF2alpha to inhibit LH-stimulated P4 secretion in Day-10 luteal cells was examined under conditions in which an elevation in $[\mathrm{Ca}(2+)]$ i had been buffered by means of the intracellular calcium chelator, Bapta-AM.

PKCepsilon expression was reduced 65 and $75 \%$ by 72 and $96 \mathrm{~h}$ after transfection, respectively. In cells in which PKCepsilon expression was ablated by $75 \%$, the inhibitory effect of PGF2alpha on LH-stimulated P4 secretion was only $29 \%$ lower than in the LH-stimulated group. In contrast, it was reduced by $75 \%$ in the group where PKCepsilon expression had not been reduced $(P<0.05)$. Real time PCR analysis indicated that there were no differences in the expression of cyclooxygenase-2 (COX-2), aldoketoreductase IB5 (AKRIB5), prostaglandin E synthase (PGES), hydroxyprostaglandin-I5 dehydrogenase (PGDH) and PGE2 -9-reductase as a function of PKCepsilon down-regulation. Finally, LH stimulated secretion of P4 at each luteal stage (Day -4 and - 10), and PGF2alpha inhibited this only in Day - 10 cells $(P<0.05)$. When A23 I87 was used at concentrations greater than $0.1 \mu \mathrm{mol}$, the induced elevation in $[\mathrm{Ca}(2+)]$ i inhibited the effect of LH on secretion of P4 in Day -4 and -10 cells $(P<0.05$, Fig. 5). The inhibitory effect of PGF2alpha on LH-stimulated P4 in Day - 10 cells was reduced if an increase in $[\mathrm{Ca}(2+)]$ i was prevented with Bapta-AM. These results support the hypothesis that differential expression of PKCepsilon and an elevation of $[\mathrm{Ca}(2+)] \mathrm{i}$ are important for acquisition of luteolytic response to PGF2alpha.
\end{abstract}




\section{Background}

The corpus luteum (CL) is a transient endocrine gland whose primary secretory product is progesterone (P4). The life span of the CL and consequently the amount of P4 it secretes is regulated according to reproductive physiological status. Substances reducing P4 secretion and shortening the luteal life span are said to be luteolytic $[1,2]$.

In most species, including human beings, $\mathrm{PGF}_{2} \alpha$ is recognized as an important if not the main luteolytic factor [39]. During the ovarian cycle, the transition from early to mid-luteal phase is associated with changes in resistance/ susceptibility to the luteolysin $\mathrm{PGF}_{2} \alpha$; in cows, the CL is resistant to exogenous $\mathrm{PGF}_{2} \alpha$ prior to day 5 of the estrous cycle [10-17]. The cellular basis controlling luteal function during these physiological transitions, although studied intensely, is incompletely understood.

In steroidogenic cells of the ruminant $\mathrm{CL}, \mathrm{PGF}_{2} \alpha$ activates its plasma membrane G-protein-coupled receptor, which in turn activates the membrane-bound phosphoinositidespecific phospholipase C (PLC), yielding inositol 1,4,5trisphosphate $\left(\mathrm{IP}_{3}\right)$ and diacylglycerol [18]. Indeed, in bovine luteal cells, $\mathrm{PGF}_{2} \alpha$ stimulated phosphatidylinositol 4,5-biphosphate hydrolysis and mobilized intracellular $\mathrm{Ca}^{2+}[19]$. Accordingly, calcium and protein kinase $\mathrm{C}$ (PKC) have been shown to be the intracellular mediators of $\mathrm{PGF}_{2} \beta$ actions in luteal cells [20]. The regulatory effects of intracellular calcium concentration $\left(\left[\mathrm{Ca}^{2+}\right] \mathrm{i}\right)$ on progesterone might be biphasic as there is also evidence for a calcium requirement to support $\mathrm{P} 4$ synthesis by bovine luteal cells and $\mathrm{LH}$, a luteotrophic hormone, increases $\mathrm{IP}_{3}$, and $\left[\mathrm{Ca}^{2+}\right] \mathrm{i}$ in bovine luteal cells and in porcine granulosa cells [21-23]. Therefore, there might exist thresholds of $\left[\mathrm{Ca}^{2+}\right] \mathrm{i}$ that support or inhibit P4 synthesis.

Choudhary et al, [17] tested the ability of increasing concentrations of $\mathrm{PGF}_{2} \alpha$ to increase the $\left[\mathrm{Ca}^{2+}\right] \mathrm{i}$ in large (LLC) and small (SLC) bovine luteal cells as function of development. Day-10 steroidogenic cells were more responsive to $\mathrm{PGF}_{2} \alpha$ than Day- 4 cell. Response amplitudes and number of responding cells were significantly affected by agonist concentration, luteal development and cell type. Response amplitudes were greater in LLC than in SLC; responses of maximal amplitude were elicited with lower agonist concentrations from Day-10 than from Day -4 cells. Furthermore, on Day-10, as concentrations of $\mathrm{PGF}_{2} \alpha$ increased, larger percentages of SLC responded. Based on those results Choudhary et al proposed that the lower efficacy of $\mathrm{PGF}_{2} \alpha$ in the early CL was likely related to signal transduction differences associated with the $\mathrm{PGF}_{2} \alpha$ receptor at those two developmental stages [17].
The array of PKC isozymes expressed in whole bovine CL includes $\alpha, \beta I, \beta I I, \varepsilon$ and $\mu[24-27]$; and it has been demonstrated that the amount of PKC $\varepsilon$ expressed in the Day$10 \mathrm{CL}$ is greater than in the Day-4 CL [26]. The latter observation led Sen et al, to propose that differential expression of PKC $\varepsilon$ as a function of development could play a role in the observed transitional resistance/susceptibility to $\mathrm{PGF}_{2} \alpha$-induced luteal regression [26,27]. Sen et al, had further hypothesized that regulation of $\left[\mathrm{Ca}^{2+}\right]$ i was a cellular mechanism through which $\mathrm{PKC} \varepsilon$ could mediate actions of $\mathrm{PGF}_{2} \alpha$ on $\mathrm{P} 4$ secretion [27]. Additionally, there is evidence indicating that when bovine follicular theca cells are isolated and their luteinization is induced under in vitro tissue culture conditions, they express PKC $\delta$ [28]. As PKC $\delta$ has been reported to play an important role in other species such as in rabbits and rodents [29,30], this PKC isozyme might also be important for the physiology of the bovine ovary.

Endothelial cells of the bovine CL do not express $\mathrm{PKC} \varepsilon$, although they do express the other PKC isozymes described in the bovine CL [31]. Data obtained with Western blot and immunohistological assays indicated that steroidogenic cells are the main source of PKCE in the bovine CL [31]. Therefore, in experiment 1, in order to assess the potential physiological role of $\mathrm{PKC} \varepsilon$, we have used a siRNA strategy to down- regulate the expression of this PKC isozyme in luteal steroidogenic cells. In experiment 2, we used the PKC $\varepsilon$ down-regulated cells to test two hypotheses. Our first working hypothesis was that PKC\& expression was necessary for $\mathrm{PGF}_{2} \alpha$ to inhibit LH-stimulated $\mathrm{P}_{4}$ secretion in vitro. The second working hypothesis was that $\mathrm{PKC} \varepsilon$ was necessary for the expression of key genes of prostaglandin synthesis/metabolism that would favor $\mathrm{PGF}_{2} \alpha$ synthesis; whereas in $\mathrm{PKC} \varepsilon$ down regulated cells, the expression of key genes of prostaglandin synthesis/metabolism would be such that synthesis of PGE2 would be favored. Finally, in experiment 3, we tested the hypothesis that $\left[\mathrm{Ca}^{2+}\right] \mathrm{i}$ is the cellular mechanism through which $\mathrm{PGF}_{2} \alpha$ inhibits luteal progesterone. We reasoned that if a pharmacological treatment is used to increase $\left[\mathrm{Ca}^{2+}\right] \mathrm{i}$, this should inhibit luteal progesterone secretion with equally effectiveness, regardless of the developmental stage of the CL. Therefore, we used a pharmacological agent to increase $\left[\mathrm{Ca}^{2+}\right] \mathrm{i}$ and examine its effects on $\mathrm{LH}$ induced $\mathrm{P}_{4}$ secretion in luteal cells collected from early (Day -4) and mid-cycle (Day -10) bovine CL. Furthermore, this hypothesis was also tested by using a pharmacological agent to buffer any increase in $\left[\mathrm{Ca}^{2+}\right] \mathrm{i}$ and examine, under conditions of low $\left[\mathrm{Ca}^{2+}\right] \mathrm{i}$, the anti-steroidogenic effect of $\mathrm{PGF}_{2} \alpha$ on LH-induced P4 synthesis/ secretion in cultures of luteal cells collected from midcycle (Day -10) CL. 


\section{Methods \\ Tissue collection}

Non-lactating beef (experiments 1 and 2) or dairy (experiment 3) cows were observed visually for estrus twice daily at approximately 12-h intervals for a minimum of $30 \mathrm{~min}$ per observation. The day when standing estrus was observed was designated as Day 0 [32]. For experiments 1 and 2, the CL from four beef cows on Day- 6 of the estrous cycle were collected in ice-cold saline and transported to the laboratory for luteal cell dispersion as described below. For experiment 3, 14 non-lactating dairy cows were synchronized with $25 \mathrm{mg} \mathrm{PGF}_{2} \alpha$ analog (Lutalyse ${ }^{\circledR}$; Pfizer Animal Health., New York, NY) and ovaries on Day $-4(n=4)$ or CL on Day $-10(n=10)$ were collected surgically as described below and transported to the laboratory in ice-cold saline for dissociation and luteal cell enrichment as described below. The surgical procedure was performed via supravaginal incision under epidural anesthesia. For the epidural anesthesia, 6-9 ml 2\% lidocaine were administered for cows weighing 450-700 kg (Butler Company, Columbus, $\mathrm{OH}$ ). After surgery, penicillin (300,000 units) was administered intramuscularly to protect against post-surgical infection. The CL or ovary was collected into ice-cold phosphate buffered saline (PBS) at pH 7.4 and transported to the laboratory within 15 to 30 min after collection. The Animal Care and Use Committee of West Virginia University approved all procedures for these experiments (ACUC protocol \# 060401).

\section{Luteal cell dispersion and purification}

In the laboratory, the CL was dissected free of connective tissue, weighed, placed into cell dispersion medium (CDM, M-199 containing 0.1\% BSA, 25 mM Hepes, 100 $\mathrm{U} / \mathrm{ml}$ fungicide), and cut into small (about $1 \mathrm{~mm}^{3}$ ) fragments. The tissue fragments were processed for tissue dissociation as previously described [17]. Luteal endothelial cells were separated by a procedure previously described [17,33-35]. Briefly, magnetic tosylactivated beads (Dynal Biotech, Lake Success, NY) were used to separate endothelial cells and the non-adherent cells, steroidogenicenriched luteal cells) were collected [33-35]. The cell population designated as steroidogenic cells represented a heterogeneous population of cells including fibroblasts, pericytes, lymphoid and possibly few endothelial cells not removed by the separation procedure. Cell viability and density were determined using Trypan Blue exclusion and a hemocytometer; luteal cell viability was usually greater than $96 \%$.

\section{Experiment I}

Validation of siRNA methodology for specifically downregulating $\mathrm{PKC} \varepsilon$ expression in enriched steroidogenic luteal cells.
Day-6 dissociated luteal steroidogenic cells were cultured overnight at a cell density of $1 \times 10^{6}$ cells/well in $35 \mathrm{~mm}$ 24 - well culture dishes (Corning Inc, Corning NY) containing $1 \mathrm{ml}$ Medium 199 supplemented with 5\% fetal calf serum (FCS, GIBCO) at $37^{\circ} \mathrm{C}\left(95 \%\right.$ air, 5\% CO $\left.{ }^{2}\right)$. The next day cells were transiently transfected with PKC 8 -specific siRNA kit (Upstate Cell Signaling solutions, Lake Placid NY) using lipofectin 2000 kit (Invitrogen Life Technologies) following the procedure recommended by the manufacturer. After transfection for $4 \mathrm{hr}$, the cultures were provided with M199 supplemented with 10\% FCS, and incubated for a total of 48,72 or 96 hours. After each of these time points, the cells were collected by adding $2 \mathrm{ml}$ M199 containing $0.25 \%$ trypsin (GIBCO) to cover the monolayer and leaving the culture dish for about $1 \mathrm{~min}$ at room temperature. The cells were aspirated and washed one time with M199 containing 5\%FCS and once with M199 without FCS. Cells collected from duplicate wells were pooled and the efficiency of transfection at 48, 72 and $96 \mathrm{~h}$ was analyzed by RT-PCR and Western blot analysis. Control groups included cells cultured in presence of M199 alone, M199 and transfecting reagent, and cells treated with non-specific siRNA duplex (non-specific siRNA).

\section{Experiment 2}

Effects of down-regulating PKC $\mathrm{P}$ expression by the siRNA protocol on: A) the ability of $\mathrm{PGF}_{2} \alpha$ to inhibit the LHstimulated P4 accumulation, and $\mathrm{B}$ ) on the expression of key genes involved in prostaglandin synthesis and metabolism.

Hypothesis 1: PKCE is necessary for $\mathrm{PGF}_{2} \alpha$ to be able to inhibit $\mathrm{P}_{4}$ secretion. To examine the ability of $\mathrm{PGF}_{2} \alpha$ (Cayman Chemical, Ann Arbor, MI) to inhibit LH-induced progesterone accumulation, the siRNA transfected and control cells (not treated with PKC $\varepsilon$ siRNA) were treated, after $96 \mathrm{~h}$, with $100 \mathrm{ng} / \mathrm{ml}$ of LH, $1000 \mathrm{ng} / \mathrm{ml}$ of $\mathrm{PGF}_{2} \alpha$, or a combination of $\mathrm{LH}$ and $\mathrm{PGF}_{2} \alpha$ for $4 \mathrm{hrs}$. After this time, the cell free medium was collected from each treatment and frozen until determination of P4 by radioimmunoassay (RIA). The RIA used for measurements of P4 in the culture media has been described previously [36]. The standard curve for this RIA ranged from $10 \mathrm{pg} / \mathrm{ml}$ to 800 $\mathrm{pg} / \mathrm{ml}$, and the intra- and interassay coefficients of variation were $9.2 \%$ and $12.8 \%$, respectively.

Hypothesis 2: PKCE is necessary for the expression of key prostaglandin biosynthetic/metabolizing enzymes. For the real time quantitative determination of gene expression of key prostaglandin biosynthetic/metabolizing enzymes in PKC $\varepsilon$ down-regulated and control (not downregulated) cells, RNA samples were obtained from the cells collected in the experiment described under Hypothesis 1. The genes examined were: aldoketoredutase 1B5 
(AKR1B5), prostaglandin-15 dehydrogenase (PGDH), prostaglandin E synthase (PGES), prostaglandin E-2-9redutase, and cyclooxygenase-2 (COX-2). Enriched steroidogenic cells were treated with the PKC $\varepsilon$ siRNA protocol and after $96 \mathrm{~h}$ of culture the cells were treated with $\mathrm{LH}$ $(100 \mathrm{ng} / \mathrm{ml}), \mathrm{PGF}_{2} \alpha(1000 \mathrm{ng} / \mathrm{ml})$, or a combination of $\mathrm{LH}$ and $\mathrm{PGF}_{2} \alpha$ for $4 \mathrm{~h}$. The cells were collected by a brief trypsin treatment and total RNA was isolated with Trizol reagent according to the manufacturer's instructions (GIBCO). Total RNA was quantified spectroscopically at $260 \mathrm{~nm}$ and integrity of the RNA was determined by $2 \%$ agarose gel electrophoresis. Specific primers were designed by using primer 3 software. The primer sequences and their accession numbers are shown in table 1. The single-step RT-PCR was carried out and cDNA product for each gene was column purified. Ten-fold serial dilutions of cDNA for each of the genes were used as templates to generate standard curves. Total RNA samples were reverse transcribed and used as templates in an iQ5 cycler (Bio-Rad Laboratories, Hercules, CA). The $25 \mu \mathrm{l}$ reaction mixture contained $12.5 \mu$ l SYBER green mix (BioRad Laboratories), $2 \mu$ cDNA sample, $2.5 \mu$ l each sense and antisense primers $(0.5 \mu \mathrm{mol})$ and $5.5 \mu \mathrm{l}$ of RNAse free $\mathrm{H}_{2} \mathrm{O}$. The standard curves of threshold cycle (ct value) versus log starting quantity for the genes of interest were obtained. The conditions used were as follows: inactivation of RT enzyme, $95^{\circ} \mathrm{C} / 3 \mathrm{~min}$; denaturation, $95^{\circ} \mathrm{C} / 30$ sec; annealing, $55^{\circ} \mathrm{C} / 30 \mathrm{sec}$; and extension, $72^{\circ} \mathrm{C} / 1 \mathrm{~min}$ with fluorescence acquisition. The melt-curves were generated from $55^{\circ} \mathrm{C}$ to $95^{\circ} \mathrm{C}$ with $0.5^{\circ} \mathrm{C}$ increments in temperature. The melt-curves were observed for presence of single amplification product. The slope and intercept values obtained from the standard curve were used to determine the starting quantity for each gene using linear regression equation and gene expression for the desired gene was normalized using $\beta$-actin as the reference gene.

\section{Experiment 3}

The working hypothesis was that a rise in $\left[\mathrm{Ca}^{2+}\right] \mathrm{i}$ is the cellular mechanism through which $\mathrm{PGF}_{2} \alpha$ inhibits luteal P4.

Effect of a pharmacological increase in $\left[\mathrm{Ca}^{2+}\right]$ i on the $\mathrm{LH}$ stimulated P4 synthesis/secretion in Day-4 and -10 luteal steroidogenic cells. We predicted that if $\left[\mathrm{Ca}^{2+}\right] \mathrm{i}$ is increased by a pharmacological treatment, this increase in $\left[\mathrm{Ca}^{2+}\right] \mathrm{i}$ should be equally effective in reducing the LH-stimulated P4 secretion regardless of the developmental stage of the CL. The enriched steroidogenic cells $\left(1 \times 10^{5}\right.$ cells/well $)$ isolated from Day-10 and Day-4 CL of PGF $2 \alpha$-synchronized non-lactating dairy cows were cultured overnight in 15 mm 24 -well culture plates in medium M199 supplemented with $0.1 \%$ BSA and $0.5 \%$ FCS. The next morning, the cells were treated in duplicate wells for $24 \mathrm{hr}$ with M199 (control), LH (100 ng/ml), PGF $2 \alpha,(1.0 \mu \mathrm{g} / \mathrm{ml})$, and a combination of $\mathrm{LH}$ and $\mathrm{PGF}_{2} \alpha$. The ability of increasing concentrations of the calcium ionophore, A23187 (0.1, 1, 10, or $100 \mu \mathrm{mol}$, (Invitrogen Detection Technologies), to inhibit basal and LH -stimulated P4 synthesis/secretion was tested in duplicate wells. The medium for the control group contained $0.1 \%$ dimethylsufoxide (DMSO, Pierce Rockport, IL), the solvent used for $\mathrm{PGF}_{2} \alpha$ and A23187. The cell-free media were collected and frozen until later measurements of P4 by RIA. The concentrations of A23187 used were based on single-cell studies, in which a concentration of $1 \mu \mathrm{mol}$ A23187 was usually effective in increasing $\left[\mathrm{Ca}^{2+}\right] \mathrm{i}$ to values comparable to those seen when cells were stimulated with $\mathrm{PGF}_{2} \alpha$ at a concentration of $1000 \mathrm{ng} / \mathrm{ml}$. The concentration range used of the $\mathrm{Ca}^{2+}$ ionophore should assure a very good probability of eliciting a wide range in increases in $\left[\mathrm{Ca}^{2+}\right] \mathrm{i}$ that would allow testing its effect on the LH-stimulated P4 synthesis/secretion in Day-4 and -10 steroidogenic cells.

Table I: Primer sequence, accession number, product size and annealing temperature of investigated genes

\begin{tabular}{|c|c|c|c|c|}
\hline Gene & Primers & Acc\# & Size & Annealing \\
\hline$\beta$-Actin & $\begin{array}{l}\text { F5'GACATCCGCAAGGACCTCTA3' } \\
\text { R5' ACGGAGTACTTGCGCTCAG3' }\end{array}$ & $\mathrm{BCl} 02948$ & 100 & $*$ \\
\hline PGDH & $\begin{array}{l}\text { F5'GGAAAGCTGGACATCTTGGT3' } \\
\text { R5'GCAAATTGCGTTCAGTCTCA3' }\end{array}$ & $\underline{\mathrm{BCl}} 02458$ & 150 & $60^{\circ} \mathrm{C}$ \\
\hline PGES-I & $\begin{array}{l}\text { F 5'GAACGACCCAGATGTGGAA3' } \\
\text { R5'ATACGGCCCAGGAAGAAGAC3' }\end{array}$ & NM 174443 & 153 & $59^{\circ} \mathrm{C}$ \\
\hline AKRIB5 & $\begin{array}{l}\text { F 5' GACCTTGGGTACCGTCACAT3' } \\
\text { R5'TCTTTCTCACTGGGAATCACG3' }\end{array}$ & $\underline{\mathrm{S} 54973}$ & 150 & $59^{\circ} \mathrm{C}$ \\
\hline PGE2 9- Reductase & $\begin{array}{l}\text { F 5'AAGAAATGCAGCCGTGAACT 3' } \\
\text { R 5' GCTCCTTCTTCTGGGCTTTT 3' }\end{array}$ & $\underline{\mathrm{BC} 102943}$ & 155 & $59^{\circ} \mathrm{C}$ \\
\hline $\operatorname{cox}-2$ & $\begin{array}{l}\text { F5'CATGATGTTCTTTGTTGGCATT3' } \\
\text { R 5' GCGAATTCCAACTTTCCATC } 3 \text { ' }\end{array}$ & AF031698 & 154 & $60^{\circ} \mathrm{C}$ \\
\hline
\end{tabular}

- Actin was amplified under the same conditions as gene of interest 
If the $\mathrm{PGF}_{2} \alpha$-stimulated increase in $\left[\mathrm{Ca}^{2+}\right] i$ is prevented, $P_{F_{2}} \alpha \mathrm{T}$ will not be able to inhibit P4 synthesis/secretion. This experiment examined the ability of $\mathrm{PGF}_{2} \alpha$ to inhibit LHstimulated P4 secretion in Day-10 luteal cells under conditions in which elevations in $\left[\mathrm{Ca}^{2+}\right]$ i were buffered. This was accomplished by testing the effect of 1,2-bis(2-aminophenoxy)ethane- $\mathrm{N}, \mathrm{N}, \mathrm{N}^{\prime}$, N'-teyracetic acid tetrakis acetomethyl ester, Bapta-AM (Invitrogen Detection Technologies, Carlsbad, CA), an effective pharmacological agent known to buffer changes in $\left[\mathrm{Ca}^{2+}\right] \mathrm{i}[37,38]$. The concentration range chosen, 0.1 to $1000 \mu \mathrm{mol}$, was based on preliminary single-cell studies indicating that at the concentration of $10 \mu \mathrm{mol}$, Bapta-AM effectively prevented the typical increase in $\left[\mathrm{Ca}^{2+}\right] \mathrm{i}$ induced by $\mathrm{PGF}_{2}$ in luteal steroidogenic cells. The enriched Day-10 steroidogenic cells $\left(1 \times 10^{5}\right.$ cells/well $)$ isolated as described above were cultured overnight in $15 \mathrm{~mm} 24$-well culture plates in medium M199 supplemented with $0.1 \%$ BSA and $0.5 \%$ FCS. The next morning, the cells were treated in duplicate wells for $24 \mathrm{hr}$ with M199 (control), LH (100 ng/ml), $\mathrm{PGF}_{2} \alpha,(1.0 \mu \mathrm{g} / \mathrm{ml})$, and a combination of $\mathrm{LH}$ and $\mathrm{PGF}_{2} \alpha$ with increasing concentration of Bapta-AM $(0.1,1,10$, 100 or $1000 \mu \mathrm{mol})$. The effect of each treatment on basal and LH -stimulated P4 synthesis/secretion was tested in duplicate wells. The medium for the control group contained 0.1\% dimethylsufoxide (DMSO, Pierce Rockport, IL), the solvent used for $\mathrm{PGF}_{2} \alpha$ and Bapta. The cell-free media were collected and frozen until later measurements of P4 by RIA.

\section{Semi-quantitative RT-PCR}

The time-course effectiveness of the siRNA treatment in down-regulating $\mathrm{PKC} \varepsilon$ mRNA expression was determined by a semi-quantitative RT-PCR procedure (RT-PCR, Qiagen, Valencia, CA) previously validated and described [24]. In this RT-PCR assay, PKCe expression was normalized to the expression of GAPDH as the reference gene. The sequence of the PKC $\varepsilon$ and GAPDH primers were those previously published: [17], sense 5'-AGCTTGAAGCCCACAGCCTG-3'; antisense 5'-CTTGTGGCCGTTGACCTGATG-3'; and (34), sense 5'TGTTCCAGTATGATTCCACCC-3'; antisense 5'- TGTTCCAGTATGATTCCACCC-3' respectively. The specificity for these primer sets have been documented $(17,24)$, and confirmed here by using the nucleotide database of National Center for Biotechnology Information [39] with BLAST software. The RT-PCR assay conditions were as follows: $50^{\circ} \mathrm{C}$ for $30 \mathrm{~min}$ for reverse transcription reaction, $95^{\circ} \mathrm{C}$ for $15 \mathrm{~min}$ for inactivation of RT enzyme, and then for PCR cycles consisted of $95^{\circ} \mathrm{C}$ for 50 seconds for denaturing, $58^{\circ} \mathrm{C}$ for 30 seconds for annealing, $72^{\circ} \mathrm{C}$ for $1 \mathrm{~min}$ for extension and a final extension of $5 \mathrm{~min}$ at $72^{\circ} \mathrm{C}$. The RT-PCR products were electrophoresed on $2 \%$ agarose gel stained with ethidium bromide and viewed using the Fluro-S MultiImager (Bio-Rad Laboratories). Data were collected using densitometric analysis of Quantity One quantification software package (Version 4, Bio-Rad Laboratories). The intensity of the signal corresponding to PKC isozyme was standardized by the corresponding intensity of GAPDH control in that sample.

\section{Semi-quantitative Western blots}

Proteins were isolated from cells of siRNA treated and control groups using previously described methodology [24]. Details for the semi-quantitative Western blot protocol used here have been described elsewhere [26]. Briefly, protein samples $(10 \mu \mathrm{g} /$ lane $)$ were resolved on an $8 \%$ polyacrylamide gel. The resolved proteins were transferred to polyvinylidene fluoride membrane (Biotechnology Systems, Boston, MA). The membranes were treated for immunodetection of the proteins of interest. The following primary antibodies were used: a mouse anti-actin monoclonal antibody ([used at a dilution of 1:3000 (v/v] Chemichon International, Inc., Temecula, CA); PKC isozyme specific $(\alpha, \beta \mathrm{I}, \beta \mathrm{II}, \varepsilon$, ) polyclonal antibodies and their antigenic peptides ([antibodies used at dilution 1:1000] Gibco, Grand Island, NY). The following horseradish peroxidase-conjugated secondary antibodies were used here: anti-rabbit (1:5000, v/v; Amersham Pharmacia Biotech, and anti-mouse $(1: 30,000 \mathrm{v} / \mathrm{v}$; GIBCO). Densitometry of the bands of interest were performed using Quantity One quantitation software. The intensity of the signal corresponding to the protein of interest was standardized by the corresponding intensity of the actin control in that sample. This normalization of data allows an estimate, in a semi quantitative manner, the amount of protein in the samples of interest, as described earlier [26].

\section{Statistics}

The statistical software program from Statistical Analysis System, JMP 3.0 was used for data analyses [40]. Data were expressed as means \pm SEM for all the experiments. One-way ANOVA was used to determine effects of different treatments. Tukey - Kramer HSD was used to compare the different treatments subgroups. A value of $\mathrm{P}<0.05$ was considered statistically significant.

\section{Results \\ Experiment I}

Culturing steroidogenic cells collected from the Day -6 CL spontaneously induced the expression of PKCE (data not shown). Expression of PKC $\varepsilon$ was induced gradually by the tissue culture conditions, and as Day- 6 luteal cells were cultured up to 6 days, PKC $\varepsilon$ expression had been spontaneously increased to values comparable to those seen in Day-10 CL (data not shown).

Fig. 1A shows a typical result of the time-course siRNA experiments performed. The summarized data shown in Fig. $1 \mathrm{~B}$ indicate that there was a significant $(\mathrm{P}<0.05)$ 
A

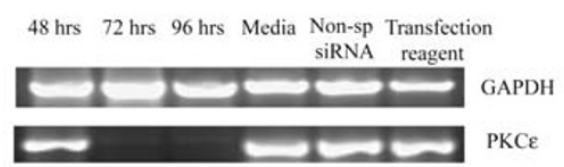

B

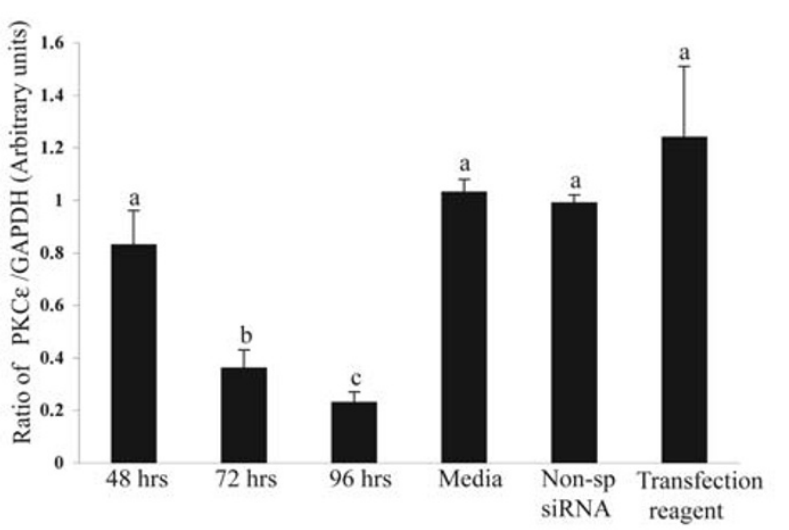

Figure I

Time-course reduction in PKC $\varepsilon$ mRNA expression after transfection of luteal steroidogenic cells with $\mathrm{PKC} \varepsilon$ specific siRNA. (A) Representative RT-PCR products obtained from total RNA using the PKC $\varepsilon$ and GAPDH primers. The amount of total RNA was adjusted to $200 \mathrm{ng}$ per reaction and 40 cycles were used for $\mathrm{PKC} \varepsilon$; while 28 cycles were used for GAPDH. The size of the amplified products for the GAPDH and PKC $\varepsilon$ were 900 and 500 bp, respectively. PKC $\varepsilon$ and GAPDH mRNA expression after 48, 72, and $96 \mathrm{~h}$ of transfection with $\mathrm{PKC} \varepsilon$ specific siRNA are shown. Lanes labeled Media, non-specific (Non-sp) siRNA, and Transfection reagent represent respective treatments without $\mathrm{PKC} \varepsilon$ specific siRNA treatment. GAPDH was used as the control gene to normalize the PKC $\varepsilon$ mRNA expression. (B) Quantitative analysis of the RT-PCR products obtained in four $(n=4)$ replicates similar to those shown in panel A. Data are the mean mean \pm SEM of the densitometry measurements for PKC $\varepsilon$ relative to GAPDH mRNA. Statistical comparisons were made between different treatments. Different letters above each SEM represent different values $(P<0.05)$.

decrease in the amounts of mRNA encoding PKC $\varepsilon$ after 72 $\mathrm{h}$ of transfection $(0.36 \pm 0.07)$ compared to the mediatreated control group $(1.03 \pm 0.05)$. Panels A and B in Fig. 1 show that this approach reduced PKC $\varepsilon$ expression 65 and $75 \%(0.23 \pm 0.04)$ by 72 and 96 hrs of treatment respectively. This reduction was specific because no similar changes were observed in treatments receiving only experimental media (Media), receiving non-specific siRNA duplexes (Non-Sp siRNA), or receiving only transfection reagents (Transfection reagent, Fig. 1B).
The effectiveness of the siRNA transfection in reducing protein corresponding to $\mathrm{PKC} \varepsilon$ can be seen in the semiquantitative western blotting (Fig 2A). A visual reduction in protein was detected $72 \mathrm{~h}$ after transfection (Fig. 2A). However, the semi-quantitative analysis of the data indicated that a significant reduction $(\mathrm{P}<0.05)$ in the amount of PKC $\varepsilon$ protein had not occurred until $96 \mathrm{~h}$ after transfection. At this time, there was a $50 \%$ reduction in the siRNA -treated group $(0.39 \pm 0.02)$ compared to control group $(0.82 \pm 0.07$, Media, Fig. $2 \mathrm{~B})$. Figure 3 demonstrates the specificity of the siRNA transfection in down-regulating the PKC 8 isozyme. This Western blot was carried out for other PKC isozymes, PKC $\alpha$ and PKC $\beta$ II, and there was no reduction in the amounts of these isozyme proteins even at $96 \mathrm{~h}$ after transfection with PKC $\varepsilon$-specific siRNA; a time by which there was significant reduction in PKCe (Fig. 2B).

\section{Experiment 2}

Hypothesis 1: Effect of PKCE down-regulation on the ability of $\mathrm{PGF}_{2} \alpha$ to decrease the LH-induced P4 accumulation. Enriched steroidogenic cells $(n=4)$ transfected with PKC $\varepsilon$ siRNA were cultured for $96 \mathrm{~h}$ and treated with $\mathrm{LH}, \mathrm{PGF}_{2} \alpha$, and combination of $\mathrm{LH}$ and $\mathrm{PGF}_{2} \alpha$ for $4 \mathrm{~h}$. The control group included cells treated with the hormones described above, but expressing normal amount of PKCe. PKC $\varepsilon$ down-regulation did not induce a decrease in the amount of P4 accumulation in the LH-stimulated cells (158.4 \pm $18.1)$ compared to the control $(202.4 \pm 11.4)$. As in previous experiments, the accumulation of $\mathrm{P}_{4}$ was significantly reduced $(\mathrm{P}<0.05)$ by $\mathrm{PGF}_{2} \alpha(42.9 \pm 2.6)$ compared to $\mathrm{LH}$ -treated control group $(202.4 \pm 11.4)$. There was no difference in the amounts of accumulated P4 between $\mathrm{PGF}_{2} \alpha$ treated PKC $\varepsilon$ down-regulated cells $(34.9 \pm 8.1)$ and control group $(42.9 \pm 2.6)$. However, the ability of $\mathrm{PGF}_{2} \alpha$ to decrease LH-stimulated P4 accumulation was significantly $(\mathrm{P}<0.05)$ inhibited in the PKC $\varepsilon$ down-regulated group, $124.4 \pm 7.4$ compared to control, $51.4 \pm 4.1$ (Fig. 4 ).

Hypothesis 2: Gene expression of key prostaglandin biosynthetic/metabolizing enzymesin PKCE down-regulated cells. Real-time PCR analysis of total RNA for mRNA encoding Cox-2, AKR1B5, PGES, PGDH and PGE (2) -9-ketoreductase indicated that there were no significant differences in the expression of any of these genes as a functions of PKC $\varepsilon$ down-regulation, $\mathrm{LH}$ or $\mathrm{PGF}_{2} \alpha$ treatment (data not shown).

\section{Experiment 3}

A rise in $\left[\mathrm{Ca}^{2+}\right] i$ is the cellular mechanism through which $\mathrm{PGF}_{2} \alpha$ inhibits luteal P4.

Effect of a pharmacological increase in $\left[\mathrm{Ca}^{2+}\right]$ i on the LH-stimulated P4 synthesis/secretion in Day-4 and -10 luteal steroidogenic cells. As reported in previous studies [17], basal P4 


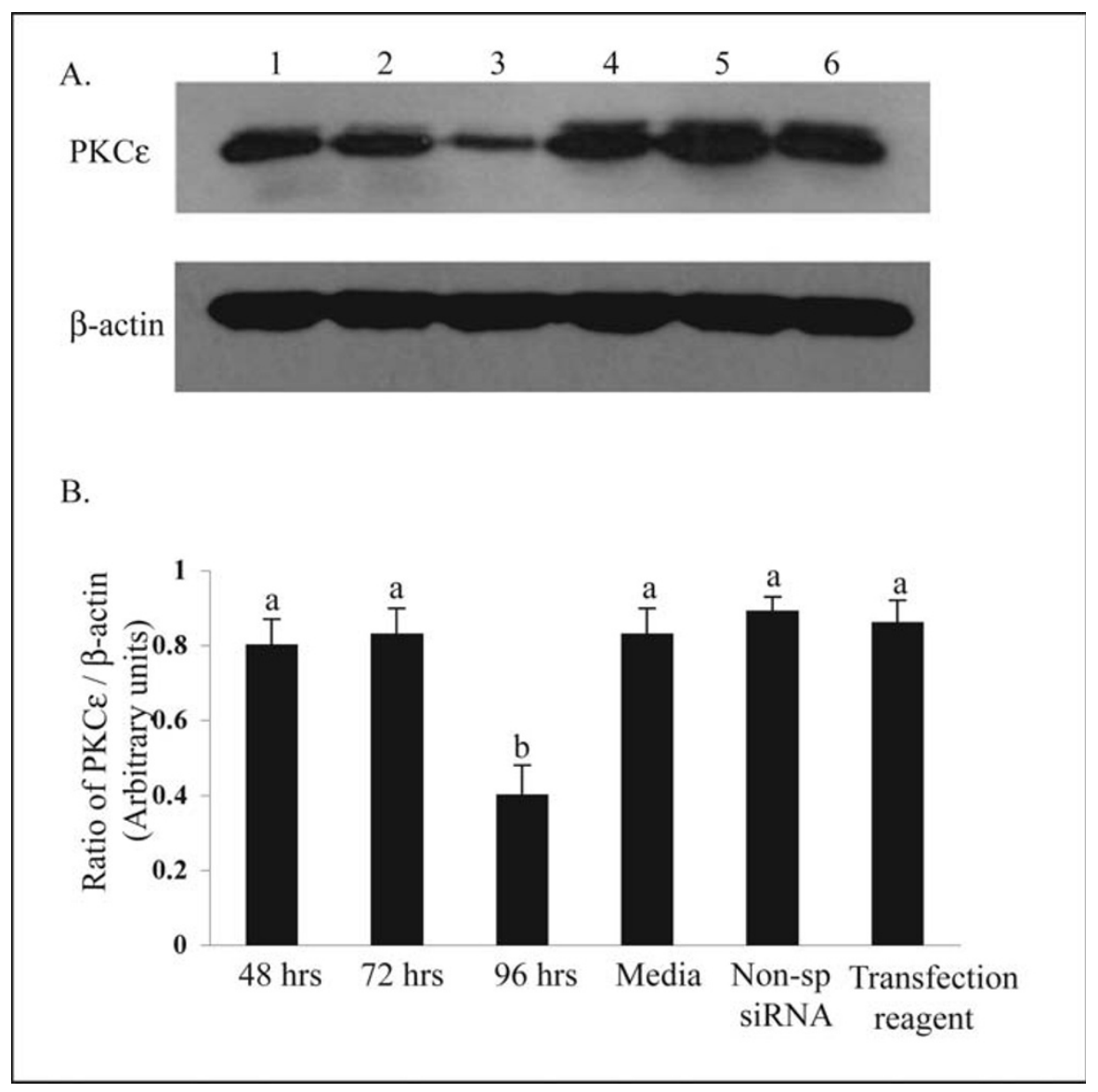

\section{Figure 2}

Reduction in PKC $\varepsilon$ protein. (A) Representative Western blot showing the amount of PKC $\varepsilon$ and actin expressed in protein samples prepared from luteal steroidogenic cells after 48, 72, and $96 \mathrm{~h}$ of transfection with PKC $\varepsilon$ specific siRNA (lanes I-3). Lanes labeled 4-6, contained protein samples from indicated control treatments (media, Non-sp siRNA, and transfection reagent, respectively). (B) Semi-quantitative analysis of the densitometry derived from four experiments similar to the one shown in panel $A$. the $y$-axis shows the ratio of the optical density ratio of $P K C \varepsilon$ to that of its corresponding $\beta$-actin. The data are shown as mean \pm SEM, and comparisons were made between different treatments. Values with different letters denote differences by one-way ANOVA followed by Tukey-Kramer honestly significant difference $(P<0.05)$.

accumulation in cells collected form Day -4 CL was significantly lower than in those collected from Day $-10(7.6 \pm$ 2.2 and $29.2 \pm 1.8$ respectively, Fig. 5A and 5B). LH significantly increased $(\mathrm{P}<0.05)$ the luteal progesterone accumulation in both Day- $4(49.5 \pm 16.3)$ and -10 cells $(65.7$ $\pm 3.7)$. This effect of $\mathrm{LH}$ was not inhibited by $\mathrm{PGF}_{2} \alpha$ in Day- 4 cells $(44.6 \pm 17.5)$, whereas it was significantly inhibited in Day-10 cells $(31 \pm 1.9$, Fig. 5A and 5B). When used at $0.1 \mu \mathrm{mol}, \mathrm{A} 23187 \mathrm{did}$ not reduce LH-stimulated P4 accumulation in Day -4 or -10 cells; but at higher concentration $(1.0-100 \mu \mathrm{mol})$, it negated the stimulatory effect of LH on P4 $(\mathrm{P}<0.05$, Fig. 5A - B). Basal P4 accumulation in Day -4 and -10 cells was not affected by any concentrations of A23187 tested (Fig. 5A and 5B, only $100 \mu \mathrm{mol}$ A23187 shown).
If the $\mathrm{PGF}_{2} \alpha$-stimulated increase in $\left[\mathrm{Ca}^{2+}\right] i$ is prevented, $\mathrm{PGF}_{2} \alpha \mathrm{T}$ will not be able to inhibit P4 secretion. LH significantly increased $(\mathrm{P}<0.05)$ the luteal progesterone accumulation in Day- 10 cells $(64.6 \pm 3$, Fig. 6). This effect of $\mathrm{LH}$ was completely inhibited by $\mathrm{PGF}_{2} \alpha(21.1 \pm 2.1$, Fig. 6). Importantly, basal P4 accumulation (Fig. 6) was not affected by the Bapta-AM treatment, not even the highest concentration used $(20.9 \pm 4.1)$. When Bapta-AM was used at $0.1,1,10$ and $100 \mu \mathrm{mol}$ in combination with $\mathrm{LH}$, the values on P4 accumulation became intermediate between those observe for basal and LH alone (Fig. 6); and the stimulatory effect of LH was completely eliminated by $1000 \mu \mathrm{mol}$ Bapta (data not shown). Consequently, the effect of Bapta-AM on the anti-steroidogenic action of $\mathrm{PGF}_{2} \alpha$ could only be tested up to $100 \mu \mathrm{mol}$. The inhibitory effect of $\mathrm{PGF}_{2} \alpha$ on LH-stimulated luteal P4 
A.

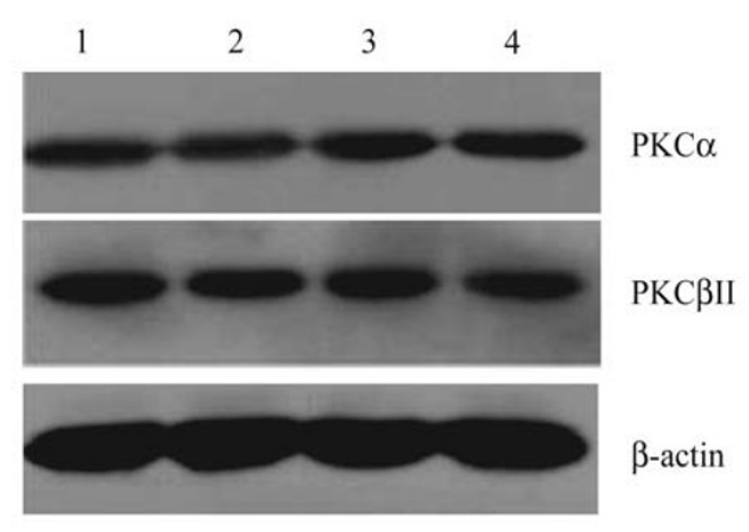

B.

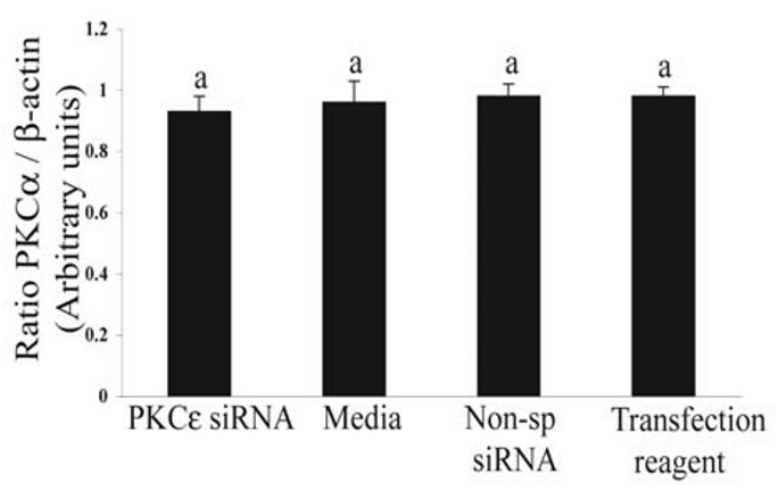

C.

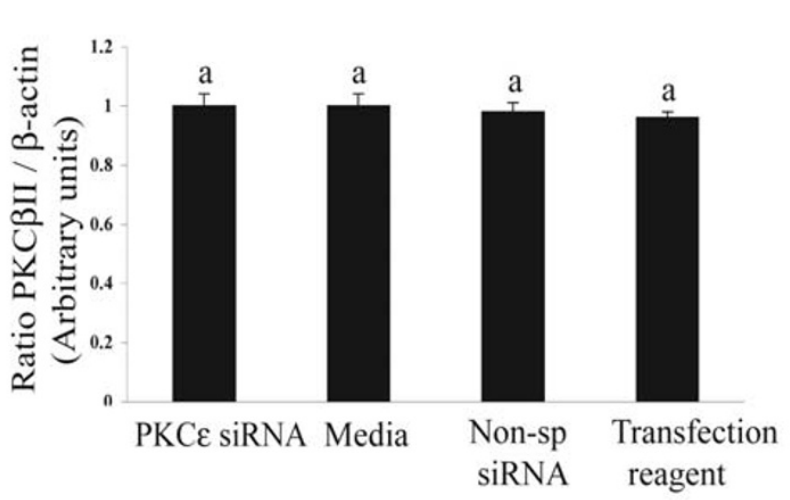

Figure 3

PKC $\alpha$ and PKC $\beta I I$ protein after $96 \mathrm{~h}$ transfection of luteal steroidogenic cells with PKC $\varepsilon$ specific siRNA. (A) Representative Western blot showing the amount of PKC $\alpha, P K C \beta I I K C \varepsilon$ and actin detected in protein samples prepared from luteal steroidogenic cells after $96 \mathrm{~h}$ of transfection with PKC $\varepsilon$ specific siRNA (lane I). Lanes labeled $2-4$, contained protein samples from indicated control treatments (media, Non-sp siRNA, and transfection reagent, respectively. B and C) Semi-quantitative analysis of the densitometry derived from four experiments similar to the one shown in panel A for PKC $\alpha$ (B) and PKC $\beta$ II (C). The $y$-axis shows the ratio of the optical density ratio of PKC isozyme to that of its corresponding $\beta$-actin. The data are shown as mean \pm SEM, and comparisons were made between different treatments by one-way ANOVA followed by Tukey-Kramer honestly significant difference.

accumulation was not affected by Bapta when used at concentrations not exceeding $1 \mu \mathrm{mol}$, as the values for $\mathrm{P} 4$ accumulation clearly were not different from those observed for basal values $(\mathrm{P}<0.05$, Fig. 6). However, at 10 and $100 \mu \mathrm{mol}$, Bapta-AM effectively reduced the ability of $\mathrm{PGF}_{2} \alpha$ to inhibit the stimulatory effect of LH on P4 accumulation (Fig. 6).

\section{Discussion}

The roles of specific PKC isozymes in luteal physiology have received little attention to date. As discussed below, these studies were designed to test the effects of ablating
PKC $\varepsilon$ expression in order to examine its hypothesized function. Previous studies had indicated that a potential function for PKC $\varepsilon$ might be to regulate quantitatively the intracellular calcium signal initiated by $\mathrm{PGF}_{2} \alpha$ on one of its luteal targets, the steroidogenic cells. The present studies validate the effective and specific down-regulation of PKC $\varepsilon$ by siRNA technology and provide strong evidence about the function of this PKC isozyme in luteal physiology. The data support the overall hypothesis that downregulating expression of $\mathrm{PKC} \varepsilon$ reduces the effectiveness of $\mathrm{PGF}_{2} \alpha$ in reducing progesterone synthesis/secretion. This observation extends the report that when PKC $\varepsilon$ was inhib- 


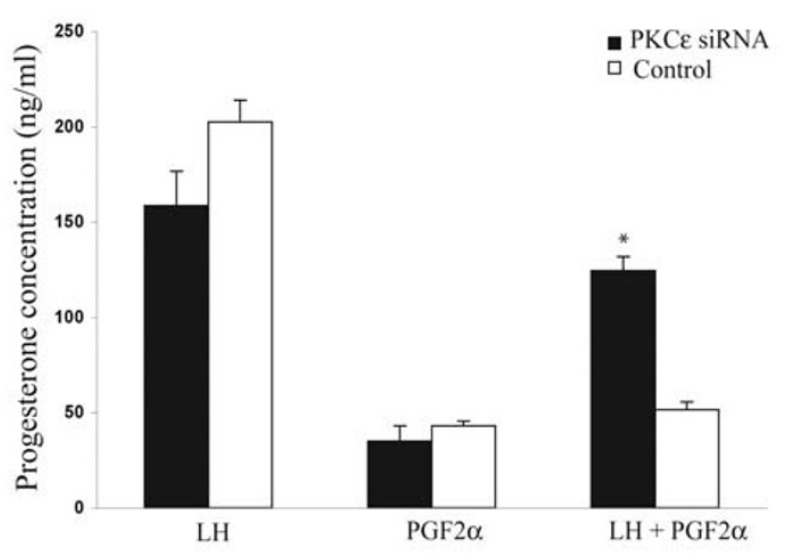

Figure 4

Effects of PKC $\varepsilon$ down-regulation on the ability of $\mathrm{PGF}_{2} \alpha$ to inhibit the $\mathrm{LH}$-stimulated progesterone synthesis/secretion in cultures of steroidogenic luteal cells transfected for $96 \mathrm{~h}$ with PKC $\varepsilon$ specific siRNA (filled bars) or with transfection regents (control, open bars). Progesterone accumulation was determined in culture media after $4 \mathrm{~h}$ of incubation in the following treatments: $\mathrm{LH}(100 \mathrm{ng} / \mathrm{ml}), \mathrm{PGF}_{2} \alpha(\mathrm{I} \mu \mathrm{g} / \mathrm{ml})$ and a combination of $\mathrm{PGF}_{2} \alpha$ and $\mathrm{LH}$. Data are presented as mean \pm SEM of four individual replicates ( $n=4$ cows). For each treatment group, statistical comparisons were made between PKC $\varepsilon$ down-regulated (PKC $\varepsilon$ siRNA) and control (not PKC $\varepsilon$ down-regulated); different letters above each SEM denote different values, $P<0.05$.

ited with $\mathrm{PKC} \varepsilon$-specific inhibitors, the $\mathrm{PGF}_{2} \alpha$ - induced rise in $\left[\mathrm{Ca}^{2+}\right]$ i was decreased in LLC and SLC and that this in turn had consequences (at least in part) in the ability of $\mathrm{PGF}_{2} \alpha$ to inhibit LH-stimulated P4 secretion at this developmental stage [27]. As previously reported [17], LH induced an increase in the amount of P4 secretion. Interestingly, in the group where PKC $\varepsilon$ expression was down regulated, the inhibitory effect of $\mathrm{PGF}_{2} \alpha$ on LH-stimulated P4 secretion was significantly mitigated (Fig. 3). This observation has an important physiological corollary: both $\mathrm{PGF}_{2} \alpha$-receptors and PKC $\varepsilon$ are expressed in the same luteal cell type. Therefore, the isozyme PKCe has an important compatible time (mid-luteal phase) and place (small and large luteal steroidogenic cells) of expression, for it to have a role in the luteal transition from resistance to sensitivity to luteolytic actions of $\mathrm{PGF}_{2} \alpha$. Furthermore, if PKC $\mathrm{P}$ expression is down -regulated (this study) or if its activation is inhibited [27], the anti-steroidogenic effect of $\mathrm{PGF}_{2} \alpha$ on LH-stimulated P4 secretion is impaired.

Experiment 2 also tested the hypothesis that down-regulating PKC $\varepsilon$ could influence the expression of key PG metabolizing enzymes that, in turn, could influence the balance of PG production from luteo-protective or luteo- trophic to luteolytic. The mechanism for luteal resistance is not exactly known. However there is now evidence that regulation of key PG metabolizing enzymes observed during physiological states in which the life span of the CL is modified is likely to play an important role in this complex process [41-49]. The selection of the examined genes was based on the available evidence that, because of their key positions in the PG biosynthetic pathway, these genes have been shown to determine the accumulation of luteolytic or luteotrophic classes of PG [40-45]. For example, we examined the effects of down-regulating РКС $\varepsilon$ on the expression of $\mathrm{PGE}_{2}$ and $\mathrm{F}$ synthases because of their more direct effect on determining whether PGH2 is metabolized to $\mathrm{PGE}_{2}$ or $\mathrm{PGF}_{2} \alpha$. The results obtained were unexpected; the prediction was that because of low expression of PKC $\varepsilon$, exogenous $\mathrm{PGF}_{2} \alpha$ would not be able to induce high increases in the cytosolic concentration of calcium, and consequently, the expression of $\mathrm{PGE}_{2}$ synthase $/ \mathrm{PGF}_{2} \alpha$ synthase ratio would favor $\mathrm{PGE}_{2}$ synthesis. The above conditions would favor luteal function. However, it is worth pointing out the importance of looking beyond steady states of mRNA encoding these enzymes; sometimes regulation may be at the level of protein or even enzyme activity and additional work is necessary before rejecting the tested hypothesis.

The developmental significance of a regulatory role played by cytosolic calcium concentrations in mediating the inhibitory actions of $\mathrm{PGF}_{2} \alpha$ is documented by results obtained in experiment 3 . As reported in previous studies [17], $\mathrm{PGF}_{2} \alpha$ reduced LH-stimulated P4 secretion in Day10 cells only. Basal P4 secretion was not affected by the $\mathrm{PGF}_{2} \alpha$-treatment at any of the two developmental stages tested. As the working hypothesis predicted, the pharmacological increase in $\left[\mathrm{Ca}^{2+}\right] \mathrm{i}$ induced by A23187 effectively mimicked the inhibitory effect of $\mathrm{PGF}_{2} \alpha$ in Day -10 steroidogenic cells. Furthermore, as predicted by the working hypothesis, the A23187 treatment also inhibited LH-stimulated P4 secretion in Day -4 steroidogenic cells. This inhibitory effect of A23187 is most likely due to its demonstrated effect in increasing the intracellular concentration of calcium ions [27] in these cells and not due to other non-specific effects. This interpretation is also supported by the observation that treatment with A23187 had no negative effect on basal P4 secretion at any of the two developmental stages tested.

Further support for the significance of a regulatory role played by the increase in $\left[\mathrm{Ca}^{2+}\right] \mathrm{i}$ in mediating the inhibitory actions of $\mathrm{PGF}_{2} \alpha$ is documented by results obtained in experiment 3 where the cytoplasmic calcium buffering capacity of the cells was increased by Bapta-AM. At lower concentrations ( 0.1 and $1.0 \mu \mathrm{mol})$, the calcium buffering capacity of Bapta-AM was, most likely, at values that still allowed a $\mathrm{PGF}_{2} \alpha$-stimulated increase in $\left[\mathrm{Ca}^{2+}\right] \mathrm{i}$; which in 
A.
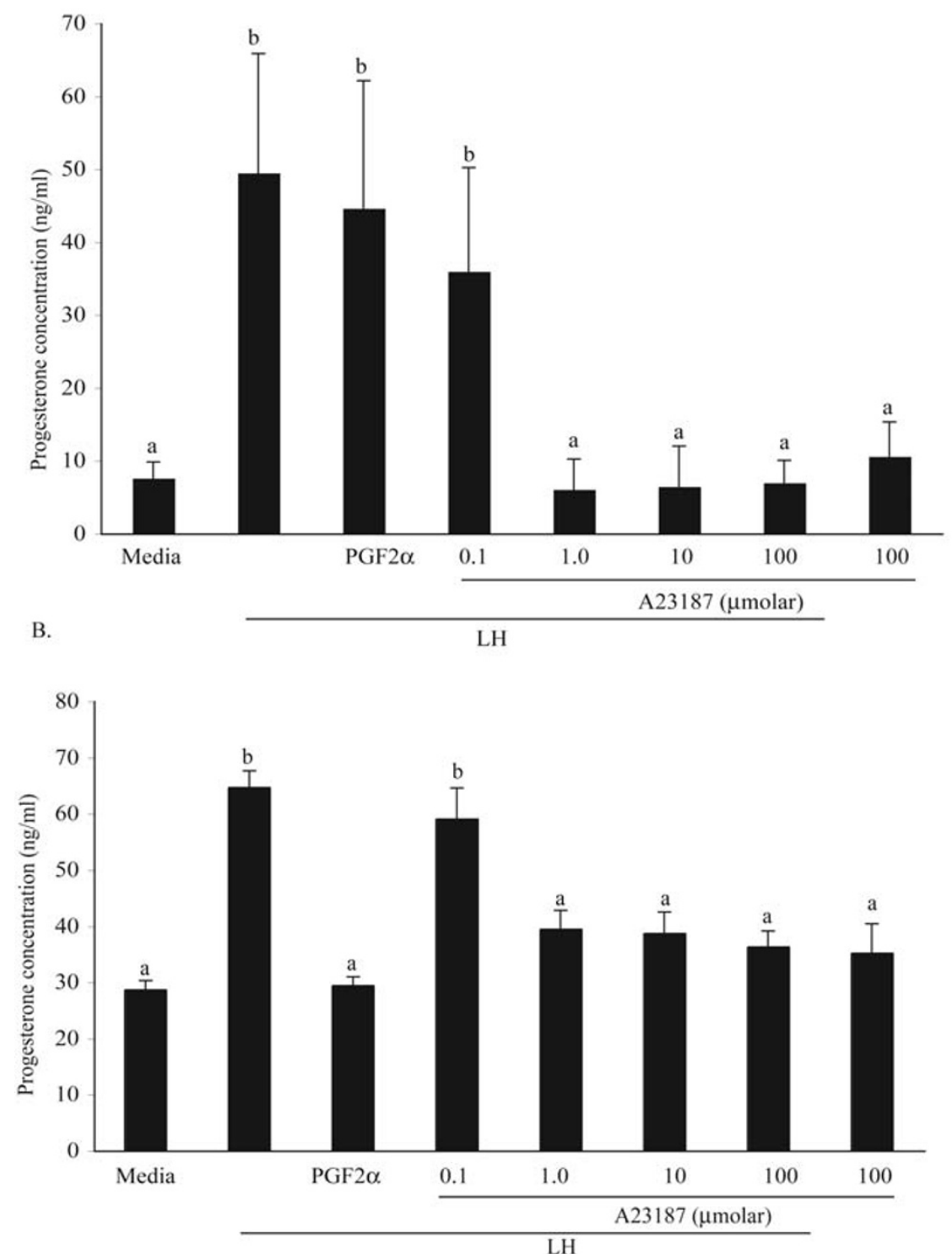

\section{Figure 5}

Effect of the $\mathrm{Ca}^{2+}$ ionophore, A23187, on basal and LH-stimulated progesterone synthesis/secretion (ng/ml) in cultured steroidogenic cells collected from Day 4 (panel A) and Day 10 (panel B) bovine CL. Progesterone accumulated in culture media was determined after $4 \mathrm{~h}$ of incubation in the following treatments: media alone (Media), LH (I00 ng/ml), LH and PGF $2 \alpha(1000$ $\mathrm{ng} / \mathrm{ml})$, or $\mathrm{LH}$ and A23I87 (0.1, I, I0, and $100 \mu \mathrm{mol})$. As explained in Materials and Methods, these treatments also contained $0.1 \%$ of the solvent used for $\mathrm{PGF}_{2} \alpha$ and A23 I87, DMSO. Data are presented as the mean \pm SEM of four Day 4 and 10 Day 10 individual replicates $(n=4$ and 10 cows respectively). Statistical comparisons were made across treatments, and means with different letters, differ within each panel $(P<0.05)$.

turn, preserved the ability of $\mathrm{PGF}_{2} \alpha$ to inhibit LH-stimulated P4 secretion (Fig. 6). However, as the calcium buffering capacity in the cytoplasm of the steroidogenic cells was increased by increasing the concentration of BaptaAM (10 and $100 \mu \mathrm{mol})$, the calcium signaling feature of activating the $\mathrm{PGF}_{2} \alpha$ receptors was most likely eliminated or at least reduced, and consequently, the ability of $\mathrm{PGF}_{2} \alpha$ to inhibit LH-stimulated $\mathrm{P}_{4}$ secretion was also significantly reduced (Fig. 6). Similar effects of Bapta-AM on basal and hormonal-stimulated steroidogenesis have 


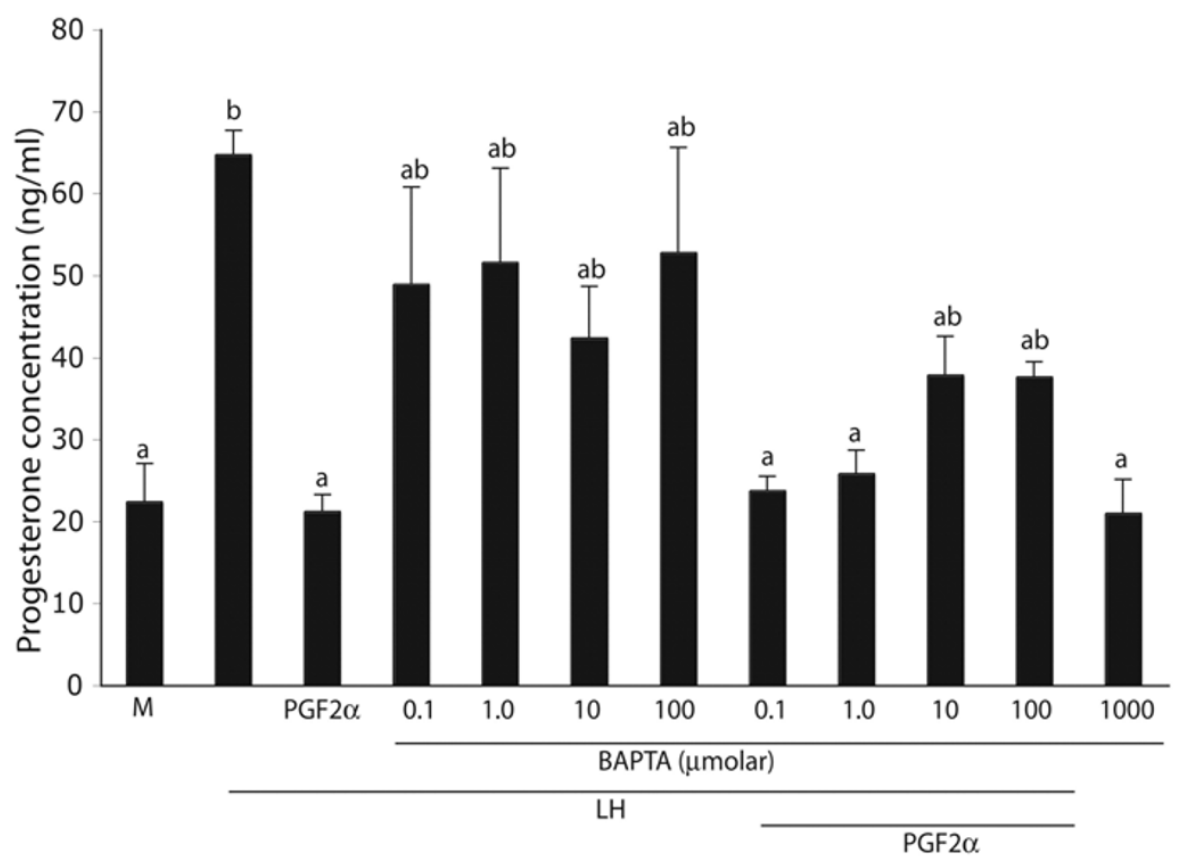

\section{Figure 6}

Effect of the cell-permeable calcium chelator, Bapta-AM, on basal and LH-stimulated progesterone synthesis/secretion (ng/ml) in cultured steroidogenic cells collected Day 10 bovine CL. Progesterone accumulated in culture media was determined after 4 $\mathrm{h}$ of incubation in the following treatments: media alone (Media), LH (I00 ng/ml), LH and PGF $\alpha$ (I000 ng/ml), or LH and Bapta-AM (0.I, I, I0, and $100 \mu \mathrm{mol})$. As explained in Materials and Methods, these treatments also contained $0.1 \%$ of the solvent used for $\mathrm{PGF}_{2} \alpha$ and Bapta-AM, DMSO. Data are presented as the mean \pm SEM of four Day I0 individual replicates $(\mathrm{n}=4$ $\mathrm{CL}$ obtained from 4 cows). Statistical comparisons were made across treatments, and means with different letters denote different values, $P<0.05$.

been reported in MA-10 Leydig cells (34). Therefore, the results of experiment 3 stress the calcium requirement for $\mathrm{PGF}_{2} \alpha$ to inhibit LH-stimulated $\mathrm{P}_{4}$ secretion in the midphase CL and support the reported observation that the lower efficacy of $\mathrm{PGF}_{2} \alpha$ to inhibit $\mathrm{P}_{4}$ secretion in the early $\mathrm{CL}$ is related to the reduced ability of $\mathrm{PGF}_{2} \alpha$ to increase the cytoplasmic concentration of calcium at this developmental stage [17]. Taken together, the results obtained in the A23187 and Bapta-AM experiments, strongly support the proposed hypothesis that an attenuation of the luteolytic actions of $\mathrm{PGF}_{2} \alpha$ is associated with a compromise in the ability of $\mathrm{PGF}_{2} \alpha$ to induce a rise in $\left[\mathrm{Ca}^{2+}\right] \mathrm{i}[27]$. Therefore these studies provide a strong linkage between the signal transduction utilized by the $\mathrm{PGF}_{2} \alpha$ receptor at different developmental stages and quantitative aspects of the known intracellular mediator of $\mathrm{PGF}_{2} \alpha$ actions in the $\mathrm{CL},\left[\mathrm{Ca}^{2+}\right] \mathrm{i}$. In this regard, species differences do exist, as in rat luteal cells the antigonadotropic action of $\mathrm{PGF}_{2} \alpha$ is not mediated by elevated cytosolic calcium levels [50]. It appears that the bovine CL therefore, has the following commonalities with human CL: 1) in both species, $\mathrm{PGF}_{2} \alpha$ is luteolysin, 2) the luteolytic effect of $\mathrm{PGF}_{2} \alpha$ appears only during mid- and late-luteal phase, and 3) in both, the humans and cows, changes in intracellular calcium appear to regulate luteal function ([51] and this study).

In summary, the evidence presented here strongly supports the idea that $\mathrm{PKC} \varepsilon$, an isozyme highly expressed in steroidogenic luteal cells with acquired luteolytic response to $\mathrm{PGF}_{2} \alpha$, has an important regulatory role in the ability of $\mathrm{PGF}_{2} \alpha$ to inhibit LH-stimulated $\mathrm{P} 4$ secretion in vitro at this developmental stage. The data presented strongly support the hypothesis that luteal resistance to the luteolytic actions of $\mathrm{PGF}_{2} \alpha$ is associated with a compromised ability of $\mathrm{PGF}_{2} \alpha$ to induce a rise in $\left[\mathrm{Ca}^{2+}\right] \mathrm{i}$. If the $\mathrm{PGF}_{2} \alpha$ receptor and its associated signal transduction is bypassed with a pharmacological agent to increase the $\left[\mathrm{Ca}^{2+}\right] \mathrm{i}$, the LH-stimulated P4 secretion in Day -4 steroidogenic cells is eliminated, an action that cannot be induced by $\mathrm{PGF}_{2} \alpha$ at this developmental stage. Conversely, if the increase in $\left[\mathrm{Ca}^{2+}\right] \mathrm{i}$ typically induced by $\mathrm{PGF}_{2} \alpha$ on Day-10 steroidogenic luteal cells is buffered by 
a pharmacological agent, then the ability of $\mathrm{PGF}_{2} \alpha$ to inhibit the LH-stimulated $\mathrm{P} 4$ secretion is abrogated.

\section{Authors' contributions}

MPG and AS made equal contributions to this study. MPG and AS were responsible for surgical procedures, all aspects of laboratory procedures, participated in the discussion, interpretation of results and in drafting the manuscript. EKI participated in the surgeries, design of the study, data analysis and drafting of the manuscript. JAF directed and participated in all aspects of the studies. All authors read and approved the final manuscript.

\section{Acknowledgements}

This study was supported in part by the Eberly College of Arts and Sciences, West Virginia University, by a Research Grant No. IS-3553-04 from BARD, the United States - Israel, Binational Agriculture Research and Development Fund, and by Hatch Project 427 (NEI 007). Appreciation is expressed to Pfizer Animal Health, New York, N. Y. for gifts of Lutalyse ${ }^{\circledR}$. This work is published with the approval of the director of the WV Agriculture and Forestry Experiment Station as Scientific Paper No. 2986 from the Division of Animal and Nutritional Science.

\section{References}

I. McCracken JA, Custer EE, Lamsa JC: Luteolysis: a neuroendocrine-mediated event. Physiol Rev 1999, 79:263-323.

2. Niswender GD, Nett TM: Corpus luteum and its control in infraprimate species. In The Physiology of Reproduction Volume I. 2nd edition. Edited by: Knobil E, Neill JD. New York: Raven Press; 1994:78I-816.

3. Patwardhan VV, Lanthier A: Concentration of prostaglandins PGE and PGF, estrone, estradiol, and progesterone in human corpora lutea. Prostaglandins 1980, 20:963-969.

4. Guthrie HD, Rexroad CE Jr, Bolt DJ: In vitro synthesis of progesterone and prostaglandin $F$ by luteal tissue and prostaglandin F by endometrial tissue from the pig. Prostaglandins 1978, 16:433-440.

5. Rexroad CE Jr, Guthrie HD: Prostaglandin F2a and progesterone release in vitro by ovine luteal tissue during induced luteolysis. Adv Exp Med Biol 1979, I I 2:639-644.

6. Pate JL: Regulation of prostaglandin synthesis by progesterone in the bovine corpus luteum. Prostaglandins 1988, 36:303-315.

7. Olofsson J, Norjavaara E, Selstam G: Synthesis of prostaglandin F2a, E2 and prostacyclin in isolated corpora lutea of adult pseudopregnant rats throughout the luteal life-span. Prostaglandins Leukotrienes Essent. Fatty Acids 1992, 46: I5I-161.

8. Arosh JA, Banu SK, Chapdelaine P, Madore E, Sirois J, Fortier MA: Prostaglandin Biosynthesis, Transport, and Signaling in Corpus Luteum: A Basis for Autoregulation of Luteal Function. Endocrinol 2004, I 45:255I-2560.

9. Auletta FJ, Flint APF: Mechanisms controlling corpus luteum function in sheep, cows, non-human primates, and women, especially in relation to the time of luteolysis. Endocr Rev 1988 , 9:88-105.

10. Silvia WJ, Niswender GD: Maintenance of the corpus luteum of early pregnancy in the ewe. III. Differences between pregnant and non-pregnant ewes in luteal responsiveness to prostaglandin $\mathbf{F}_{2} \alpha$. J Anim Sci 1984, 59:746-753.

11. Inskeep EK: Potential uses of prostaglandins in control of reproductive cycles of domestic animals. J Anim Sci 1973, 36:1149-II57.

12. Copelin JP, Smith MF, Garverick HF, Youngquist RS, McVey WR Jr, Inskeep EK: Responsiveness of bovine corpora lutea to prostaglandin F2 $\alpha$ : comparison of corpora lutea anticipated to have short or nomal lifespans. J Anim Sci 1988, 66:1236-1245.

13. Silva PJ, Juengel JL, Rollynson MK, Niswender GD: Prostaglandin metabolism in the ovine corpus luteum: catabolism of pros- taglandin $\mathrm{F}_{2}\left(\mathrm{PGF}_{2}\right)$ coincides with resistance of the corpus luteum to $\mathbf{P G F}_{2}$. Biol Reprod 2000, 63: I229-1236.

14. Tsai SJ, Wiltbank MC: Prostaglandin $F_{2}$ induces expression of prostaglandin $\mathbf{G} / \mathrm{H}$ synthetase-2 in the ovine corpus luteum: a potential positive feedback loop during luteolysis. Biol Reprod 1997, 57:1016-1022.

15. Sayre BL, Taft R, Inskeep EK, Killefer J: Increased expression of insulin-like growth factor-binding protein- $I$ during induced regression of bovine corpora lutea. Biol Reprod 2000, 63:21-29.

16. Wiltbank MC, Shio TF, Bergfelt DR, Ginther OJ: Prostaglandin $\mathbf{P G F}_{2} \alpha$ receptors in the early bovine corpus luteum. Biol Reprod 1995, 52:74-78.

17. Choudhary C, Sen A, Inskeep EK, Flores JA: Developmental sensitivity of the bovine corpus luteum (CL) to prostaglandin $F_{2}$ $\left(P G F_{2}\right)$ and endothelin-I: is ET-I a mediator of the luteolytic actions of $\mathrm{PGF}_{2}$ or a tonic inhibitor of progesterone secretion. Biol Reprod 2005, 72:633-642.

18. Davis JS, Alila HW, West LA, Corradino RA, Hansel W: Acute effects of prostaglandin $F 2 \alpha$ on inositol phospholipid hydrolysis in the large and small cells of bovine corpus luteum. Mol Cell Endo 1988, 58:43-50.

19. Davis JS, Weakland LL, Weiland DA, Fares RV, West LA: Prostaglandin F2 alpha stimulates phosphatidylinositol 4,5-bisphosphate hydrolysis and mobilizes intracellular calcium in bovine luteal cells. Proc Natl Acad Sci USA 1 987, 84:3728-3732.

20. Wiltbank MC, Diskin MG, Niswender GD: Differential actions of second messenger system in the corpus luteum. J Reprod Fertil Suppl I 99I, 43:65-75.

21. Davis JS, Weakland LL, Farese RV, West LA: Luteinizing hormone increases inositol trisphosphate and cytosolic free $\mathrm{Ca2}+$ in isolated bovine luteal cells. J Biol Chem 1987, 262:85 I5-852 I.

22. Flores JA, Aguirre C, Sharma Om P, Veldhuis JD: Luteinizing Hormone (LH) Stimulates Both Intracellular Calcium Ion $\left(\left[\mathrm{Ca}^{2+}\right]_{\mathrm{i}}\right)$ Mobilization and Transmembrane Cation Influx in Single Ovarian (Granulosa) Cells: Recruitment as a Cellular Mechanism of $\mathrm{LH}-\left[\mathrm{Ca}^{2+}\right]_{\mathrm{i}}$ Dose Response. Endocrinol 1998, 139:3606-3612

23. Alila HW, Davis JS, Dowd JP, Corrodino RA, Hansel W: Differential effects of calcium on progesterone production in small and large bovine luteal cells. J Steroid Biochem 1990, 36:387-693.

24. Orwig KE, Bertrand JE, Ou BR, Forsber NE, Stormshak F: Immunochemical characterization and cellular distribution of protein kinase $\mathbf{C}$ isozymes in the bovine corpus luteum. Comp Biochem Physiol 1994, 108(I):53-57.

25. Davis JS, May JV, Keel BA: Mechanisms of hormone and growth factor action in the bovine corpus luteum. Theriogenology 1996, 45: $1351-1380$.

26. Sen A, Browning J, Inskeep EK, Lewis P, Flores JA: Expression and activation of protein kinase $C$ isozymes by prostaglandin $F$ $\left(\mathrm{PGF}_{2} \alpha\right)$ in the early- and mid-luteal phase bovine corpus luteum. Biol Reprod 2004, 70:379-384.

27. Sen A, Choudhary E, Inskeep EK, Flores JA: Effects of selective protein kinase $C$ isozymes in prostaglandin $F 2 \alpha$-induced $\mathrm{Ca}^{2+}$ signaling and luteinizing hormone-induced progesterone accumulation in the mid-phase bovine corpus luteum. Biol Reprod 2005, 71:976-98.

28. Budnik LT, Mukhopadhyay AK: Lysophosphatidic acid-induced nuclear localization of protein kinase $\mathbf{C} \delta$ in bovine theca cells stimulated with luteinizing hormone. Biol Reprod 2002, 67:935-944.

29. Maizels ET, Shanmugan M, Lamm M, Hunzicker-Dunn M: Hormonal regulation of PKC-delta protein and mRNA levels in thje rabbit corpus luteum. Mol Cell Endocrinol 1996, I22:213-22I.

30. Peters CA, Maizels ET, Robertson MC, Shiu RP, Sololoff MS, Hunzicker-Dunn M: Induction of relaxin messenger RNA expression in response to prolactin receptor activation requires protein kinase C-delta signaling. Mol Endocrinol 2000, 14:576-590.

31. Sen A, Wright M, Inskeep EK, Flores JA: Participation of specific PKC isozymes in the inhibitory effect of ET-I on progesterone accumulation in cells isolated from early-and mid-phase corpora lutea. Domest Anim Endocrinol 2006, 3 1:284299.

32. Casida LE: Research techniques in physiology of reproduction in the female. In Techniques and Procedures in Animal Production Research Edited by: Chapman AB. Albany, NY: American Society of Animal Production; 1959:106-121. 
33. Mamluk R, Chen D, Greber Y, Davis J, Meidan R: Characterization of prostaglandin F2 $\alpha$ and $L H$ receptors mRNA expression in different bovine luteal cell types. Biol Reprod I998, 58:849-856.

34. Levy N, Gordin M, Mamluk R, Yanagisawa M, Smith MF, Hampton JH, Meidan R: Distinct Cellular Localization and Regulation of Endothelin-I and Endothelin-Converting Enzyme-I Expression in the Bovine Corpus Luteum: Implications for Luteolysis. Endocrinology 200I, I 42:5254-5260.

35. Webb BL, Lindsay MA, Seybold J, Brand NJ, Yacoub MH, Haddad E: Identification of the protein kinase $\mathbf{C}$ isoenzymes in human lung and airways smooth muscle at the protein and mRNA level. Biochem Pharmacol 1997, 54:99-205.

36. Sheffel CE, Pratt BR, Ferrell WL, Inskeep EK: Induced corpora lutea in the postpartum beef cow. II. Effects of treatment with progestogen and gonadotropins. J Anim Sci 1982, 54:830-836.

37. Midzak AS, Liu J, Zirkin BR, Chen H: Effect of Myxothiazol on Leydig Cell Steroidogenesis: Inhibition of Luteinizing Hormonemediated Testosterone Synthesis but stimulation of Basal Steroidogenesis in MA-10 Leydig Cells. Endocrinology 2007, | 48:2583-2590.

38. Nikonenko M, Bancila M, Bloc A, Muller D, Bijlenko P: Inhibition of T-Type Calcium Channels Protects Neurons Delayed Ischemia-Induced Damage. Mol Pharmacol 2005, 68:84-89.

39. NCBI [http://www.ncbi.nlm.nih.gov/entrez/query.fcgi?.DB=pubmed]

40. Statistical software for the Apple Macintosh. JMP Statistics and Graphics Guide. In Version 3.0 of JMP Cary, NC: Statistical Analysis System.

41. Asselin E, Fortier MA: Detection and regulation of the messenger for a putative bovine endometrial 9- keto-prostaglandin $E_{2}$ reductase: Effect of oxytocin and interferon-tau. Biol Reprod 2000, 62:|25-|3|.

42. Asselin E, Bazer FW, Fortier MA: INF-tau increases PGE $_{2}$ production and COX-2 gene expression in the bovine endometrium in vitro. Mol Cell Endocrinology 1997, I32: I I7-I26.

43. Xiao CW, Liu JM, Sirois J, Goff AK: Regulation of cyclooxygenase -2 and prostaglandin $F$ synthase gene expression by steroid hormones and interferon-tau in bovine endometrial cells. Endocrinology 1998, 139:2293-2299.

44. Shemesh M, Hansel W: Stimulation of prostaglandin synthesis in bovine ovarian tissues by arachidonic acid and luteinizing hormone. Biol Reprod 1975, I 3:448-452.

45. Patek CE, Watson J: Prostaglandin F and progesterone secretion by porcine endometrium and corpus luteum in vitro. Prostaglandins 1976, 12:97-III.

46. Rexroad CE Jr, Guthrie HD: Prostaglandin F2 $\alpha$ and progesterone release in vitro by ovine luteal tissue during induced luteolysis. Adv Exp Med Biol 1979, I I 2:639-644.

47. Hu Y, Sanders JDH, Kurz SG, Ottobre JS, Day ML: In vitro prostaglandin production by bovine corpora lutea destined to be normal or short lived. Biol Reprod 1990, 42:80I-807.

48. Griffeth RJ, Nett TM, Burns PD, Escudero JM, Inskeep EK, Niswender GD: Is luteal production of PGF required for luteolysis? Biol Reprod 2002, 66(supp I):465. abstract

49. Silvia PJ, Juengel JL, Rollyson MK, Niswender GD: Prostaglandin metabolism in the ovine corpus luteum: catabolism of prostaglandin $\mathbf{F}_{\mathbf{2}} \alpha\left(\mathbf{P G F}_{\mathbf{2}} \alpha\right)$ coincides with resistence of the corpus luteum to $\mathbf{P G F}_{2} \alpha$. Biol Reprod 2000, 63:1229-1236.

50. Pepperell JR, Preston SL, Berhman HR: The antigonadotropic action of prostaglandin $F_{2} \alpha$ is not mediated by elevated cytosolic calcium levels in rat luteal cells. Endocrinology 1998, I 25: |44-|5|.

5I. Ottander U, Leung CHB, Olofsson J: Functional evidence for divergent receptor activation mechanisms of luteotrophic and luteolytic events in the human corpus luteum. Molecular Human Reproduction 1999, 5:391-395.
Publish with Biomed Central and every scientist can read your work free of charge

"BioMed Central will be the most significant development for disseminating the results of biomedical research in our lifetime. "

Sir Paul Nurse, Cancer Research UK

Your research papers will be:

- available free of charge to the entire biomedical community

- peer reviewed and published immediately upon acceptance

- cited in PubMed and archived on PubMed Central

- yours - you keep the copyright

Submit your manuscript here:

http://www.biomedcentral.com/info/publishing_adv.asp
BioMedcentral 